\title{
KÖZLEMÉNY
}

\section{„Önnek hány gyermeke született?” Gyermekszámra vonatkozó kérdezési technikák és adatjavítások az Életünk fordulópontjai panelkutatásban}

\author{
Makay Zsuzsanna
}

\section{ÖSSZEFOGLALÓ}

Az Életünk fordulópontjai panelkutatás során négy alkalommal került sor ugyanazon válaszadók felkeresésére 2001 és 2012 között. Sok egyéb adat mellett gyermekeik pontos születési ideje is rögzítve lett, hiszen a kutatás egyik központi témáját képezik a gyermekvállalási döntések. Adatellenőrzések során kiderült, hogy sok esetben hibásak ezek az adatok, és ugyanazon válaszadók gyermekszáma eltér az egyes hullámok között, sok esetben csökken. Emiatt nagyszabású adatjavításra került sor, melynek célja az volt, hogy az egyes hullámokban konzekvensek legyenek a válaszadók gyermekeinek adatai, gyermekszámuk. E tanulmányban ennek a javításnak a menetét és tapasztalatait írom le, és külön részt szentelek a levonható tanulságoknak: megfelelő kérdésfeltevéssel és kérdezési technikával a hibák nagy része elkerülhető és nagymértékben javítható az adatminőség.

Tárgyszavak: Életünk fordulópontjai, adatminőség, panelkutatás, gyermekszám

Makay Zsuzsanna

KSH Népességtudományi Kutatóintézet

E-mail:makay@demografia.hu 


\section{BEVEZETÉS}

A kutatási célokra felhasznált adatok megbízhatósága alapfeltétele annak, hogy a kapott eredmények érvényesek, az adott társadalomra vonatkoztatva relevánsak legyenek. Emellett a szociológiai-demográfiai adatfelvételek esetében különösen fontos, hogy a családdal kapcsolatos adatok a lehető legközelebb álljanak a valósághoz. A termékenységgel, gyermekvállalással összefüggő elemzések készítésekor a válaszadók gyermekeinek a száma és születésük ideje az a minimális információ, amellyel már lehet (a szülő(k) egyes ismérveivel együtt) kutatásokat végezni. És noha azt gondolhatnánk, hogy ezeknek az adatoknak a begyűjtése nagyon egyszerü, valójában gyakran nem helyesek a kapott információk.

Közleményemben az Életünk fordulópontjai címú panelvizsgálat termékenység-történettel, gyermekszámmal kapcsolatos adatai összeirásának és javításának a tapasztalatait és tanulságait kívánom megosztani. A kérdőív készítése és az összeírók oktatása során néhány kiemelt szempont figyelembevételével nagymértékben javíthatjuk ugyanis az összegyüjtendő adatok minőségét.

Az Életünk fordulópontjai egy nagyszabású társadalmi-demográfiai panelkutatás, amely 16363 ember megkérdezésével indult 2001-2002 fordulóján. 2012-2013-ig összesen négy alkalommal került sor adatfelvételre ugyanazon válaszadók körében.' A követéses vizsgálat négy hullámában összesen 8103 válaszadó vett részt (1. táblázat). A résztvevők minden alkalommal kérdezőbiztos segítségével töltötték ki a hozzávetőleg egyórás kérdőívet, amelyben családi helyzetükről, gyermekeikről, tanulmányaikról, munkájukról, életkörülményeikről, aggodalmaikról és sok egyéb más témáról kérdezték őket (a kutatásról részletes leírást ad Kapitány 2003, valamint Murinkó - Spéder 2016). A kérdőív egy részére minden adatközlő válaszolt, ezt követően pedig mindenkivel az adott élethelyzetének megfelelő kérdéseket tárgyalták meg. Míg például a fiatal, gyermekvállalási korban lévő válaszadók a családalapítással, addig az idősebb, nyugdíj előtt álló generációk a nyugdíjba lépéssel kapcsolatban kaptak több kérdést. A született gyermekekre vonatkozó kérdéseket minden válaszadó megkapta mindegyik hullámban.

12016-2017 fordulóján, e cikk írása idején zajlik az 5. adatfelvételi hullám. Egyes hullámok során a minta kiegészült „fiatal”, újonnan bevont válaszadókkal, de az ő követésükre a későbbiekben nem került sor; kivéve a jelenleg zajló 5. hullámot. 
1. táblázat: Az egyes adatfelvételek ideje és a panel válaszadók száma hullámonként Year of the four waves of data collection and the number of panel respondents

$$
\text { Adatfelvétel ideje Panel résztvevők száma }
$$

$\begin{array}{lrr}\text { 1. hullám } & 2001 / 2002 & 16363 \\ \text { 2. hullám } & 2004 / 2005 & 13540 \\ \text { 3. hullám } & 2008 / 2009 & 10641 \\ \text { 4. hullám } & 2012 / 2013 & 8103\end{array}$

A kutatás a nemzetközi Generations and Gender Survey (GGS) része, melynek keretében 19 fejlett országban kérdeztek le egy nagyon hasonló kérdőívet legalább egy alkalommal. A termékenység, gyermekvállalás, szülővé válás a projekt központi tematikája; lényegében az 1990-es években (Magyarország részvételével is) lezajlott Fertility and Family Surveys (FFS) [Termékenység és Család] adatfelvétel folytatásának tekinthető. A GGS-adatokból több tucat elemzés és publikáció született; a társadalmi kérdéseket érintő kutatások mellett módszertani tanulmányok is készültek. Ennek köszönhető, hogy a válaszadók gyermekeivel, gyermekvállalási történetével kapcsolatos adatok elemzésére adatminőségi szempontokat figyelembe véve is sor került. Az adatellenőrzések során ugyanis kiderült, hogy a gyermekekre, a termékenységre vonatkozó adatok nem megfelelő minőségűek. Németországban az első hullám után vetették össze a GGS-adatokat a népmozgalmi adatokkal, és arra jutottak, hogy az előbbi a gyermekszámot az idősebb generációk esetében alulbecsüli, míg a fiatalabb generációk esetében túlbecsüli (Kreyenfeld et al. 2013). A szerzők egyenesen arra hívták fel a figyelmet, hogy ezen adatok nem eléggé megbízhatóak a kohorsz-termékenységgel kapcsolatos statisztikák számításához. Franciaországban a GGS első, második és harmadik hullámának adatait hasonlították össze egymással, így derült fény a nem megfelelő adatminőségre. Kiderült, hogy a 40 év feletti válaszadók 22\%-a a második és/vagy a harmadik hullámban alacsonyabb gyermekszámot mondott, mint korábban (Régnier-Loilier 2014). További elemzés arra világított rá, hogy az első hullámos adatok a legmegbízhatóbbak: nem az elsőben került sor „,túl sok” gyermek összeírására, hanem a későbbi hullámokból maradtak ki elsősorban elhunyt, valamint a válaszadóval nem együtt élő gyermekek.

Ezeket az eredményeket olvasva elemeztük a gyermekekkel kapcsolatos magyar adatokat adatminőségi szempontból. Kiderült, hogy ezekben is sok és különböző, ám a legtöbb esetben javitható hiba van. Jelen közleményben ezt az ellen- 
őrzési és javítási folyamatot mutatjuk be oly módon, hogy azt is megnézzük, mely tényezők vezethettek a hibás adatok rögzítéséhez. Emellett levonjuk a megfelelő tanulságokat arra vonatkozóan, hogyan érdemes feltenni a kérdéseket ahhoz, hogy a gyermekszámot és a gyermekek adatait a legmegbízhatóbban tudjuk összeírni.

Az adatok javítására egy nagyobb munka keretében került sor, mely során a Népességtudományi Kutatóintézet munkatársai igyekeztek az Életünk fordulópontjai adatgyűjtést dokumentálni, az adatokat javítani, harmonizálni, felhasználóbaráttá tenni. Ennek a munkának az is a célja volt, hogy a külső adatfelhasználók számára egyértelművé váljon, hogy mely adatbázis milyen célra használható és mit tartalmaz. Korábban ugyanis nem volt ezeknek az adatoknak verziószámuk, a bázisok hullámonként külön-külön voltak csak - bizonyos feltételek mellett - elérhetőek. ${ }^{2}$

A gyermekekkel kapcsolatos javítás során a hullámonkénti adatokat összekapcsoltuk egy nagy longitudinális adatrendszerbe, és ezen végeztük a javítást. A végső cél a longitudinális adatbázis rendbehozatala volt, de végül nem csak a mind a négy hullámra válaszoló 8103 ember adatai kerültek javításra, hanem azon 16363 emberé, akik az első hullámban részt vettek. Erről a cikk további részében részletesen szólunk. Az NKI által kiadott adatok 2016 decemberétől tartalmazzák ezeket a javításokat.

A tanulmány az alábbiak szerint épül fel: először bemutatjuk, hogy az egyes adatfelvételi hullámok során mely kérdésekkel és hogyan zajlott a gyermekek összeírása. Majd ismertetjük a gyermekszámokkal kapcsolatos adatokat, és leírjuk, miből következtettünk arra, hogy számottevő a hibás adatok aránya. Ezután ismertetjük az adatjavítás menetét, eredményét és következményeit. Végül levonjuk a következtetéseket és tanulságokat annak érdekében, hogy a későbbi adatfelvételek során a hibák nagy része elkerülhető legyen.

\section{A GYERMEKSZÁMRA VONATKOZÓ KÉRDÉSEK AZ EGYES HULLÁMOKBAN}

A demográfiai-társadalmi adatfelvételekben jellemzően kétfajta módon kerül sor a gyermekek számbavételére. Az egyik lehetőség, hogy egyszerre írnak öszsze minden gyermeket egy termékenységi blokkban, megkérve a válaszadókat, hogy adják meg egyes gyermekeik születési adatait. Így történt az adatgyűjtés a már említett FFS-felvétel során.

\footnotetext{
2 Ennek a dokumentációs - adatjavitási munkának az eredményeként született meg az Életünk fordulópontjai panelkutatás felhasználói kézikönyve (Murinkó - Spéder 2016).
} 
A másik lehetőség, melyet a GGS és így az Életünk fordulópontjai adatfelvétel is követett, hogy a kérdőívben két alkalommal kerül sor a gyermekekre: a háztartásblokkban kerülnek összeirásra a válaszadóval egy háztartásban élő gyermekei, míg ettől elkülönítve, és jellemzően valamivel később gyűjtik össze azokat a gyermekeket, akik nem élnek a válaszadóval vagy elhunytak. Ennek az eljárásnak az az előnye, hogy specifikus kérdésekkel további információkat lehet gyüjteni a két típusba sorolható gyermekekről: meg lehet kérdezni például, hogy a kérdezett milyen gyakran találkozik a máshol élő gyermekeivel, ők hol élnek, az elhunyt gyermekek mikor haltak meg, stb. Ugyanakkor hátrány, hogy fragmentálódik a gyermekekkel kapcsolatos információ, és nagyobb a hibalehetőség.

A részletes adatok összegyüjtését mindkét esetben kiegészitheti (megelőzheti) egy a gyermekszámra vonatkozó összefoglaló kérdés, mely rögzíti a válaszadó született gyermekeinek számát. Ennek a kérdésnek a hasznosságára később térünk ki.

Az Életünk fordulópontjai adatfelvétel mind a négy hullámában a második elv szerint került sor a gyermekek összeirására: a válaszadóval együtt élő gyermekei a háztartástáblába kerültek, a tőle külön élő gyermekei pedig az ún. különélő gyermekek táblába ${ }^{3}$ (kivéve a második hullámban, ahol nem volt ilyen tábla erről később lesz szó). Ebből a szempontból tehát nem változott az adatgyüjtés módszere a négy hullám során. A gyermekszámra vonatkozó, ill. a gyermekek adatainak összegyűjtését felvezető kérdések azonban igencsak eltértek az egyes hullámokban; most ezek ismertetésére kerül sor. ${ }^{4}$

Az első hullámban nem volt a gyermekszámra vonatkozó összefoglaló kérdés, az együtt élő gyermekek pedig a háztartástáblába kerültek. Az egyéb háztartástagoktól való megkülönböztetésük a rokonsági kódok segítségével történt, amelyek közül egy vonatkozott a vér szerinti gyermekekre, „saját gyermeke” elnevezéssel (1. hullám kérdőíve, 11. kérdést követő táblázat). A különélő gyermekekre vonatkozóan az alábbi kérdést tettük fel: „Született-e Önnek olyan gyermeke, akivel jelenleg nem él közös háztartásban?” (13. kérdés). Amennyiben a kérdezőbiztos igenlő választ kapott, megkérdezte, hány ilyen gyermek született, majd összeirta az adataikat. (Az első hullám háztartástáblája és a különélő gyermek tábla megtalálható a függelékben.)

A második hullámban a kérdezés logikája némiképp eltért az elsőétől. A kérdezés egy ún. élettörténeti kalendáriummal indult, ennek az volt a célja, hogy hónapokra lebontva kövesse és rögzítse azokat a családi és munkapiaci eseményeket, amelyek érintették a válaszadót az előző kérdezés óta eltelt három

\footnotetext{
${ }^{3}$ Elnevezésével ellentétben, ide kellett kerülniük minden hullámban a már elhunyt gyermekeknek is.

${ }^{4}$ A kérdőívek megtalálhatóak az http://eletunkfordulopontjai.hu honlapon a „Kutatóknak” címszó alatt.
} 
évben. A válaszadó gyermekeivel kapcsolatosan tehát ahelyett, hogy csupán két keresztmetszeti (pillanatnyi) adatunk lenne arról, hogy a gyermekek a kérdezések idején a válaszadó szülőjükkel éltek-e vagy sem, az erre vonatkozó információt összegyűjtöttük a két kérdezési hullám között eltelt időszak minden egyes hónapjára is. ${ }^{5}$ Ez úgy nézett ki, hogy az első kérdezési hullámban felsorolt összes életben lévő gyermek - függetlenül attól, hogy hol élt az első hullámban előre be volt írva a kalendáriumba. A kérdezőbiztosnak tisztáznia kellett, hogy az azóta eltelt időben az egyes gyermekek mikor éltek a kérdezettel, és eszerint kellett kitöltenie a hónapokra lebontott kalendáriumot. Emellett be kellett írnia a két kérdezés között megszületett és elhunyt gyermekeket is. Majd a kitöltés végén, mintegy összegezve a kalendáriumot és a benne megtalálható gyermekek számát, felolvasta és a kérdezettel egyeztette azt az állítást, hogy „Tehát Önnek élete során _ _ gyermeke született.” (A1. kérdés). Amennyiben ekkor kiderült, hogy a kalendáriumban nem annyi gyermek volt, ahány gyermeke született a válaszadónak, javítania kellett az adatokat. (A kalendárium megtalálható a függelékben.) A kalendárium után került sor a „rendes” kérdőív kitöltésére. Ebben nem volt különélő gyermekek tábla, az együttélő gyermekek azonban az első hullámhoz hasonlóan itt is szerepeltek a háztartástáblában. Őket két rokonsági kód szerint kellett besorolni, különbséget téve aközött, hogy a vér szerinti gyermek „a jelenlegi házas- vagy élettárssal közös gyermek” vagy „a kérdezett saját gyereke egy korábbi partnertől” (2. hullám kérdőíve, A5. kérdést követő táblázat). A válaszadóval együtt élő gyermekek tehát kétszer szerepelnek: benne vannak a háztartástáblában és a kalendáriumban is, miközben a különélő gyermekek csak a kalendáriumban szerepelnek. Egy, az összegző gyermekszámra vonatkozó megállapítás pedig a kalendárium után került kitöltésre.

A harmadik hullámban a gyermekek számbavétele úgy zajlott, mint az első hullámban. A kérdezettel élő gyermekek a háztartástáblába kerültek (ugyanazokkal a rokonsági kódokkal, mint a második hullámban; 3. hullám kérdőíve, 106. kérdés), a nem vele élők pedig a különélő gyermekek táblába. Ennek felvezető kérdése így hangzott: „Van-e Önnek olyan gyermeke, akivel jelenleg nem él közös háztartásban? Kérem, csak a vér szerinti és az örökbe fogadott gyermekeket vegye figyelembe. A nevelt gyermekeket most ne sorolja fel." (312. kérdés $)^{6}$. Igenlő válasz esetén sor került a gyermekek adatainak összeírására. A második hullámtól eltérően a tábla itt kiegészült két kérdéssel minden egyes gyermekre vonatkozóan: „[Ez a gyermek] Örökbe fogadott gyermek?”, valamint

\footnotetext{
${ }^{5}$ A kalendárium egyéb családi eseményeket is követett, ezekre nem térünk ki.

${ }^{6}$ Kiemelések a kérdőívben.
} 
„[Ez a gyermek] Vér szerinti gyermeke jelenlegi társának?”. Mindkét esetben 1-es számmal kellett jelölni az igenlő, és 2-essel a nemleges választ.

A negyedik hullámban a kérdezés technikájának megváltoztatása miatt kicsit máshogy zajlott a gyermekek összeírása. Az adatgyüjtés ekkor már nem papíros kérdőívvel, hanem laptoppal történt (angol nevén computer-assisted personal interviewing [CAPI] módszerrel), és lehetővé vált, hogy a program a kérdezés során számolja, hány gyermek adatai lettek rögzítve. A kérdések ekkor úgy néztek ki, hogy a kérdőív legelején szerepelt egy gyermekszámra vonatkozó összefoglaló kérdés, amely így hangzott: „Született-e Önnek gyermeke?” Amennyiben igen, úgy beírta a kérdezőbiztos az „élve született gyermekek” számát. Majd néhány kérdéssel később, ahogy a korábbi hullámokban, sor került a háztartásban élő gyermekek felvételére (két rokonsági kód vonatkozott a vér szerinti gyermekekre), majd következett a különélő gyermek tábla az alábbi felvezető kérdéssel: „Élve született gyermekei között van-e olyan, akivel jelenleg nem él közös háztartásban? Ha volt olyan gyermeke, aki elhunyt, kérem őt is vegye figyelembe!” "Igen” választ követően a program megnyitotta a különélő gyermekek táblát, és sor került az adatok rögzítésére. A számítógép előnyeit kihasználva arra törekedtünk, hogy a begyűjtött adatok a kérdőíven belül konzisztensek legyenek. Egyrészt kérdezői utasításban szerepelt, hogy a két táblába bevitt gyermekek számának meg kell egyeznie a bevezető kérdésben közölt adattal, másrészt a számítógépes program is ellenőrizte ezt, és amennyiben eltért a kettő, a kérdezőbiztos elnyomható hibaüzenetet kapott.

Az 2. táblázat mutatja összefoglalóan, hogy mely kérdésekkel került sor a gyermekekkel kapcsolatos adatok begyüjtésére. Míg a háztartásban élő gyermekek öszszeírása nagyon hasonló volt a négy hullámban, addig a különélő (vagy már meghalt) gyermekeké eltért olyan szempontból, hogy hullámonként más-más kérdés került felolvasásra. Az első hullámban a kérdés a született (tehát vér szerinti) gyermekekre vonatkozott, azonban a megfogalmazása olyan gyermekekre utal, akik máshol élnek, tehát életben vannak. A kérdés nem sugallja, hogy a válaszadónak az elhunyt gyermekeiről is be kell számolnia, és erre vonatkozóan nem is volt egyéb felhívás vagy pontosítás. A harmadik hullámról még inkább elmondható ugyanez, hiszen a kérdés a ,jelenleg” életben lévő gyermekekről faggatja a válaszadót. Különbséget tesz vér szerinti, örökbe fogadott és nevelt gyermekek között, de szintén nem tér ki az esetlegesen elhunytakra. A negyedik hullám kérdése precízebb minden szempontból: az „élve született” szókapcsolat használatával utal arra, hogy a válaszadónak a vér szerinti gyermekeire kell gondolnia. Emellett külön mondatban tér ki arra, hogy az elhunyt gyermekeket is említse meg. Ahogy látni fogjuk, ezek a fogalmazásbeli különbségek nagymértékben befolyásolták a begyűjtött információkat.

\footnotetext{
${ }^{7}$ Kiemelések a kérdőívben.
} 


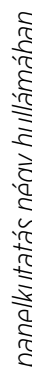

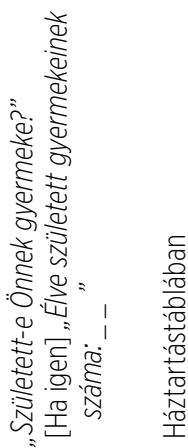

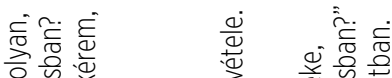

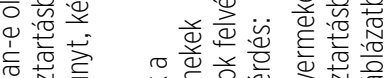

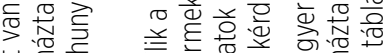

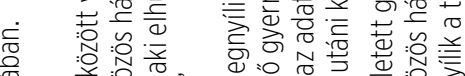
完

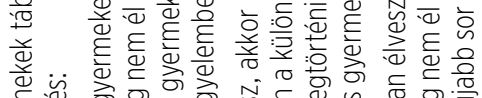

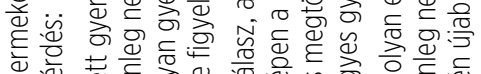

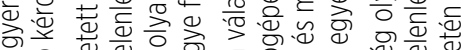
के

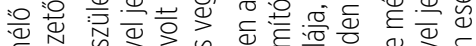

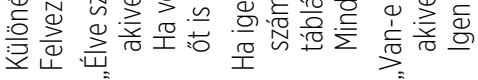
ब.

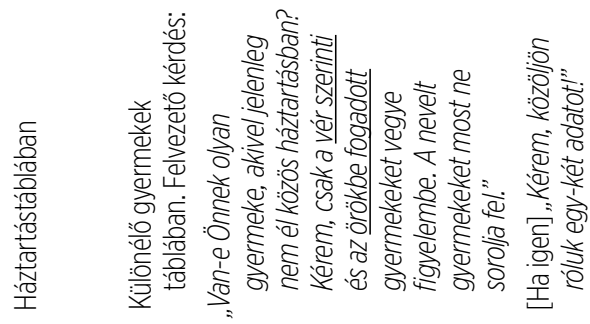

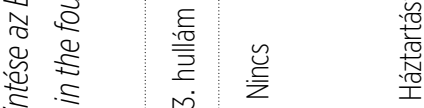

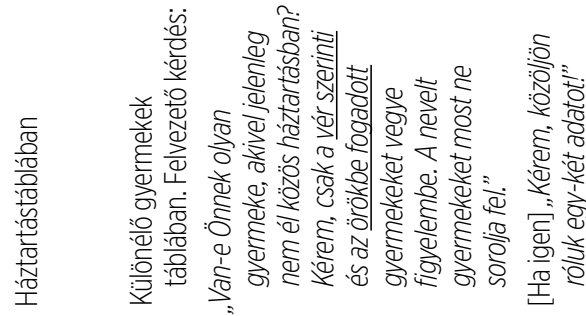

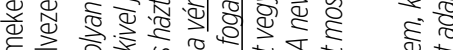
ह

et 㺃 适 还 装迹 छे : 을 娄

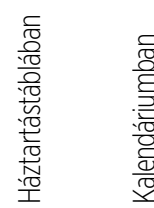
获: के 筀<smiles>[13CH]=[13CH]S</smiles>
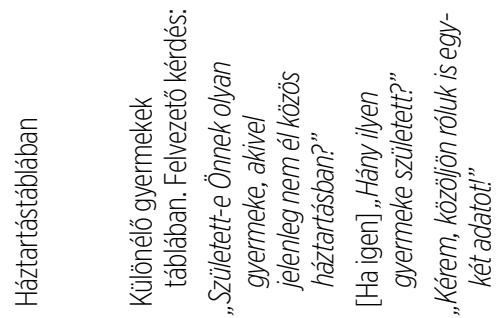


\section{A KAPOTT ADATOK ELLENŐRZÉSE}

A termékenységi, gyermekekkel kapcsolatos ún. „survey”-adatok ellenőrzésének több módja is van. A legtöbb esetben a hivatalos adatokkal (népmozgalmi vagy népszámlálási adatokkal) vetik össze őket, összehasonlítva a két forrásból származó kohorsz-termékenységet vagy a családnövekedési valószínüségeket (pl. Ní Bhrolcháin et al. 2011, Kreyenfeld et al. 2013). Ezzel lényegében a survey-adatok reprezentativitását vizsgálják, vagyis azt nézik meg, hogy mennyire általánosíthatók, mennyire felelnek meg az országos adatoknak. A longitudinális adatok esetében emellett arra is lehetőség van, hogy az adatok „önmagukkal” való konzisztenciáját ellenőrizzük le, vagyis azt nézzük meg, hogy egy-egy válaszadó mennyire adott konzisztens válaszokat egy-egy (objektív) kérdésre a különböző hullámokban. Esetünkben: egy az első hullám idején 60 éves, gyermekvállalási időszakát már lezárt női válaszadónak mind a négy válaszadási hullámban ugyanannyi gyermekről kellett volna beszámolnia, és az ő születési adatuknak meg kellene egyeznie a négy kérdőívben. Mennyiben állt fenn ez a helyzet?

Mikor először megnéztük ezeknek az adatoknak a minőségét, már akkor kiderült, hogy a hibák száma nem elenyésző: a négy hullám során a válaszadók mintegy 9,2\%-ának például csökkent a gyermekszáma, vagyis egy későbbi hullámban kevesebb gyermekről számoltak be, mint egy korábbiban. ${ }^{8}$ llyennek nem lett volna szabad előfordulnia, hiszen elvileg minden egyes hullámban összeírásra került az összes - életben lévő és elhunyt - gyermek. Felmerült, hogy vajon az első hullámban van-e túl sok gyermek (pl. bizonyos gyermekek duplán szerepelnek), vagy pedig a későbbiekben maradtak-e ki a korábban már összeírtak. Az ellenőrzések elvégzése után a második opció bizonyult valószínủbbnek. Úgy tünt, ez a jelenség leginkább a harmadik hullámot érinti: ott fordult elő a leggyakrabban, hogy korábban rögzitett gyermekek nem lettek megemlítve. Emellett azt is megállapítottuk, hogy a negyedik hullámban a korábbiakhoz képest magasabb az átlagos gyermekszám még az idősebb, reprodukciós korból már kilépett generáció estében is (Makay 2015). További elemzés azt is kimutatta, hogy igen hiányosak az adatok a már elhunyt gyermekekre vonatkozóan. Az első és harmadik hullám között csökkent az elhunyt gyermekek száma, majd a negyedik hullámban több mint duplájára nőtt ${ }^{9}$ (3. táblázat). Látszott, hogy a második hullámon belül is vannak hibák: a válaszadók

\footnotetext{
${ }^{8}$ A 8103 „Iongi” válaszadó (akik mind a négy hullámban részt vettek) válaszait figyelembe véve.

${ }^{9}$ A 8103 „longi” válaszadó válaszait figyelembe véve.
} 
közel 3\%-ánál nem egyezett a kalendáriumban szereplő gyermekszám a kalendárium után felvett „összegző” gyermekszámmal.10

3. táblázat: Az elhunyt gyermekek száma és az öket emlitô válaszadók száma az egyes hullámokban az adatjavitás elött

The number of deceased children and the number of respondents mentioning these children in the four waves of the survey before data correction

\begin{tabular}{lll}
$\begin{array}{l}\text { Adatfelvételi } \\
\text { hullám }\end{array}$ & $\begin{array}{l}\text { Hány elhunyt gyermek } \\
\text { adatai lettek rögzítve? }\end{array}$ & $\begin{array}{l}\text { Hány válaszadó számolt } \\
\text { be elhunyt gyermekről? }\end{array}$ \\
\hline $\begin{array}{l}\text { 1. hullám } \\
\text { 2. hullám }\end{array}$ & 187 elhunyt gyermek & 154 válaszadó \\
3. hullám & 114 elhunyt gyermek & 104 válaszadó \\
4. hullám & 163 elhunyt gyermek & 145 válaszadó \\
& 390 elhunyt gyermek & 358 válaszadó \\
\hline
\end{tabular}

Forrás: KSH Népességtudományi Kutatóintézet, Életünk fordulópontjai adatok, 1-4. hullám. Minta: mind a négy hullámban válaszolók, $\mathrm{N}=8103$.

E négy ok (egyik hullámról a másikra csökkenő gyermekszám; az idősebbek körében magasabb gyermekszám a negyedik hullámban; elhunyt gyermekek adatainak hiánya; inkonzisztenciák a hullámokon belül is) késztetett minket arra, hogy átnézzük, és lehetőség szerint kijavítsuk ezeket az adatokat. A továbbiakban ennek a javításnak a menetéről és következményeiről lesz szó.

\section{AZ ADATJAVÍTÁS MENETE"}

Az adatjavítás célja tehát az volt, hogy az egyes válaszadók gyermekszámra vonatkozó válaszai konzisztensek legyenek az egyes adatfelvételi hullámokban. A fent példaként említett 60 éves hölgy gyermekszáma - és lehetőség szerint a gyermekek születési ideje (elsősorban azonban a gyermekszámra összpontosítottunk) - egyezzen meg mind a négy hullámban.

Az volt tehát a célunk, hogy az adatok a javítás után megfeleljenek az alábbi három elvárásnak.

\footnotetext{
${ }^{10} 13540$ válaszadó válaszait figyelembe véve, akik válaszoltak a második hullámra. Ez részben abból adódott, hogy a kalendáriumba nem voltak az adatfelvétel előtt visszatöltve a korábban már elhunyt gyermekek, miközben a válaszadó a gyermekszámnál megemlithette őket.

"Az adatjavitást Kutrovatz Kitti végezte el.
} 
1.) A válaszadóknak egy későbbi hullámban ne legyen kevesebb gyermekük, mint egy korábbiban. Ellenkező esetben biztosan hibásak az adatok, hiszen minden egyes hullámnál az volt a cél, hogy a teljes termékenységtörténet rögzítésre kerüljön. Vagyis az esetlegesen (már régebben) elhunyt gyermekek is szerepeljenek mindegyik hullámban.

2.) Az idős, már az első hullám idején is a reprodukciós koron kívül eső válaszadóknak ne legyen több gyermekük egy későbbi hullámban, mint egy korábbiban.

3.) Amennyiben két hullám között növekedett a gyermekszám, úgy „valós” születésről legyen szó: legyenek meg az új gyermek adatai.

Gyermekszámokról beszélünk, ám mint láttuk, a négy hullámból csak kettőben van összegző gyermekszámunk. Az ellenőrzéshez különböző gyermekszám-változókat hoztunk létre, de maga a javitás valójában nem egy vagy több ilyen jellegű összegző változó átírását jelentette (kivéve a második és a negyedik hullámban, ahol ezt is jelenthette), hanem a háztartástáblákban, valamint a küIönélő gyermek táblákban előforduló gyermekek adatainak javítását.

Az előzetes elemzések alapján két okból is valószínüsithető volt, hogy a negyedik hullám adatai a legmegbízhatóbbak. Egyrészt a különélő gyermekekre való kérdésfeltevés sokkal összetettebb volt: felhívta a válaszadók figyelmét arra, hogy az összes élve született gyermekükről beszéljenek, valamint hogy elhunyt gyermekeiket is vegyék figyelembe. Másrészt a számítógépes program ellenőrizte, hogy a kérdőiven belül megfelel-e a két táblában összeirt gyermekek száma a kérdőív elején található gyermekszámmal. Az oktatások során külön felhívtuk a kérdezőbiztosok figyelmét ennek fontosságára. Ennek eredményeképpen már javítás előtt is csak 67 esetben nem egyezett a két adat (szemben a második hullám 377 esetével, amikor is az összegző változó nem egyezett a kérdőívben lévő gyermekszámmal). Az elhunyt gyermekek száma is magasabb lett, ami önmagában nem jelentené, hogy jobbak ezek az adatok (az is előfordulhatott volna, hogy pl. egyéb elhunyt családtagok is bekerülnek a táblába). Az a tény azonban, hogy korábban feltünően alacsony volt ezeknek a gyermekeknek a száma, amellett szólt, hogy ezúttal jobb arányban sikerült őket összeírni.

Javitáskor a negyedik hullám adatai így nagyobb súlyt kaptak: amennyiben ekkor kiderült, hogy elhunyt gyermeke van a válaszadónak, akkor őt beletettük a többi adatbázisba is. Ez kicsit kockázatos eljárásnak tűnhet, hiszen egyetlen kérdezés sok esetben felülírt korábbi három hullámot. Mégis mind a kérdezés megfogalmazása, mind a fentebb leírt technika valószínűsítette, hogy ezek a helyes adatok. 
A javítás folyamata leegyszerủsítve így nézett ki:

Összeadtuk hullámonként a háztartástáblában és a különélő gyermek táblában lévő vér szerinti gyermekek számát. Így kaptunk 1-1 gyermekszám-változót a négy hullámra. ${ }^{12}$

Ezeket összehasonlítottuk egymással, és azon válaszadók esetében, akiknél a számok nem feleltek meg a fent leírt három elvárásnak, elindítottuk a javitás folyamatát.

Ennek első lépéseként összehasonlítottuk hullámonként és gyermekenként azok 1) születési idejét, valamint 2) a válaszadóhoz viszonyított rokonsági kódját (amennyiben háztartástáblában lévő gyermekről volt szó) vagy 3) a különélés kezdetének idejét (amennyiben különélő gyermekről volt szó). Így általában sikerült kideríteni, hogy mely gyermek adatai, ill. hol hibásak. Kiderült például, hogy egy gyermek három hullámban szerepel a különélő gyermek táblában, de egyben kimaradt onnan. Sor kerülhetett tehát a javitásra, vagyis (ez esetben) a többi hullám alapján a hiány pótlására.

Maga a javitás állhatott abból, hogy 1) egy gyermek rokonsági kódját kellett átírni a háztartástáblában, vagy 2) a gyermeket törölni kellett (a külön élő gyermek táblából), mert nem vér szerinti gyermek volt, vagy 3) a gyermek adatait beletettük egy hullámba, ahonnan hiányzott (,visszatöltöttük”).

Noha az elsődleges cél a longitudinális adatbázis rendbetétele volt, nemcsak annak a 8103 válaszadónak az adatait javítottuk ki, akik mind a négy alkalommal válaszoltak, hanem a teljes mintáét, aszerint differenciálva a válaszadókat, hogy hány hullámra válaszoltak. Tehát aki például csak az első kettőben vett részt, annál az 1-2. hullámos adatokat javítottuk (ha kellett/lehetett); aki az első háromban, annál három hullám adatait néztük egybe, és így tovább. Hullámról hullámra haladtunk: először csak az első hullámban részt vettek adatai kerültek átnézésre ( $N=2832)$, majd csak az első két hullámban részt vetteké ( $N=2900)$, majd az első három hullámban részt vetteké ( $N=2537)$, végül pedig mind a négy hullámban részt vetteké ( $\mathrm{N}=8103)$. A megfelelő hullámokat (ahányban részt vett a válaszadó) együtt néztük meg, és a hibás eseteket vizsgálva igyekeztünk kideríteni, hogy mely hullámban található információk helyesek a legnagyobb valószínűséggel. Ha például egy válaszadó kétszer is beszámolt egy (születési ideje alapján azonositható) gyermekéről, de harmadszor már nem, akkor oda beírtuk a gyermeket. Kétes esetekben igyekeztünk megnézni a válaszadó életkorát, párkapcsolati helyzetének változását, az egyéb gyermekei adatait stb. is, hogy minél kevesebb hiba legyen a javításban. Az egyes hullámokban az adatok (javítások)

\footnotetext{
${ }^{12}$ Hullámonként még 3 másik gyermekszámot is kiszámoltunk, ezek a háztartásban lévő gyermekek számát, a különélő gyermekek számát, valamint az elhunyt gyermekek számát adták meg (ezek összege volt maga a gyermekszám).
} 
harmonizálva lettek. Ha pl. a negyedik hullámból kiderült, hogy a válaszadónak van 2 elhunyt gyermeke, akkor ezeket visszatöltöttük a korábbi három hullámba. A legtöbb esetben nem teljesen biztos, hogy helyesen javítottunk, ahogy az adatok valóságát sem tudjuk semmilyen survey-adatfelvétel során ellenőrizni. Ennek ellenére úgy gondoljuk, hogy nagyrészt helyesen történt a javítás.

A visszatöltésre is igyekeztünk néhány általános szabályt felállítani, hiszen ez a fajta javítás módosíthatja (a törlés mellett) legnagyobb mértékben az adatokat. Az alábbi elveket követtük.

Háztartástáblába nem töltöttünk vissza gyermeket. Ennek egyik oka, hogy a háztartásszerkezet függvényében tettünk fel számos kérdést, így a szerkezet megváltoztatása megtörte volna a kérdőív logikáját. A másik pedig, hogy a legtöbb hullámban rákérdeztünk a háztartás-jövedelemre, és az adat használhatósága igencsak megkérdőjeleződik, ha módosítjuk a háztartásban élő személyek számát. Így a visszatöltött gyermekek adatai mind a különélő gyermek táblába (a 2. hullámban a kalendáriumba) kerültek.

Hasonló okok miatt igyekeztünk azt az elvet is követni, hogy háztartástáblából nem törlünk gyermeket. Erre csak kivételes esetben kerülhetett sor (hét válaszadó esetében), amikor is egy hullámban duplán, mindkét táblában szerepeltek a gyermekek, ám a többi hullámból kiderült, hogy már évtizedek óta nem élnek a válaszadóval. Fontos kiemelni, hogy a törlés miatt egy esetben sem vált egyszemélyes háztartássá a válaszadó háztartása, ami ismét módosította volna a kérdezés logikáját.13

A különélő gyermek táblába való visszatöltéskor a gyermekek születési éve és hónapja, valamint a nemük került szisztematikusan visszatöltésre. Ez, amenynyiben lehetett, kiegészült a különélés éve és hónapja változóval is. Az adott gyermekre vonatkozó többi változó (pl. a válaszadó mennyire elégedett a gyermekével való kapcsolatával) hiányzó értéket kapott.

Az elhunyt gyermekek szintén a különélő gyermek táblába kerültek (helyesen odakerülnek az adatgyüjtés során is), az ő esetükben a születési évük és hónapjuk, a nemük, valamint a haláluk éve és hónapja került beírásra.

Amennyiben szükséges volt, a második és a negyedik hullámban a gyermekszámra vonatkozó összegző kérdések is javítva lettek.

\section{A JAVÍTÁS KÖVETKEZMÉNYE ÉS TANULSÁGAI}

A fent leírt eljárást követve 1640 válaszadó esetében (csak a mind a négy hullámban részt vevőket figyelembe véve 1077 válaszadónál, mintegy 13\%-uknál)

\footnotetext{
${ }^{13}$ Ezekben az esetben javitásra került a k(_)htnagy változó is (,Önnel együtt hányan élnek ebben a háztartásban?”).
} 
történt valamilyen javítás az adatokban. Összesen ennél még több, mintegy 3700 adatban történt javítás. Ennek magyarázata, hogy egy-egy javítás több változó átírásával is járt: egy gyermek adatainak visszatöltésével vagy törlésével akár 5-8 változó értéke is megváltozhatott.

A javítás eredményeként a válaszadóknak összességében több gyermekük lett. Hullámonként eltérő, hogy mennyivel, de átlagosan mintegy 410-zel nőtt a számuk a javított adatokban, ugyanazon hullám eredeti állományához képest. A 3. hullámból maradt ki az adatfelvétel során a legtöbb gyermek, itt ugyanis a korábbihoz képest 575 gyermekkel több van a javított adatokban. A válaszadók gyermekszám szerinti eloszlása is módosult valamelyest. Némiképp csökkent a gyermektelenek aránya is (4. táblázat).

Minden hullámban nőtt az elhunyt gyermekek száma a régi adatokhoz képest, hullámonként átlagosan közel 150 gyermekkel. Tehát ahogy feltételeztük, sok esetben a meghalt gyermekek maradtak ki a válaszadók beszámolóiból, ám messze nem olyan nagy mértékben, mint ahogyan ezt gondoltuk. Ezek a gyermekek is a harmadik hullámban maradtak ki a leggyakrabban: ott a javított adatokban 218 elhunyt gyermekkel van több.

A teljes javítás eredményeként lényegében megszünt az a hiba, hogy egy későbbi hullámból kimaradnak korábban bevallott gyermekek, illetve hogy az idősebb válaszadóknál későbbi hullámokban bukkannak fel gyermekeik. Emellett sok esetben a születési időpontokban is sor került korrigálásra.

A javítás után összegeztük, hogy mik voltak a leggyakoribb hibák, és melyek a levonható következtetések. A hibák jellegével kapcsolatban elmondható, hogy noha voltak típushibák, ezek a legkülönfélébb módon keveredtek egymással az egyes hullámokban és az egyes gyermekek esetében. Néhány jellemzőjük azonban jól körülhatárolható. Ilyen a rokonsági kódok elrontása, vagyis az a típushiba, hogy egy vér szerinti gyereket egy másik hullámban más rokonsági kóddal szerepeltetnek a háztartástáblában. Ez lehetett a kérdezőbiztos rontása, esetleg nem kérdezett rá pontosan a gyermek „típusára”. Az is előfordulhatott, hogy a kód a rögzítés során rosszul lett felvezetve a számítógépre, akár a rögzítő figyelmetlensége folytán, akár amiatt, hogy nem volt olvashatóan beírva a kérdőívbe (a negyedik hullám laptopos kérdezése esetén ez a hibalehetőség eltűnt). Bizonyos esetekben a válaszadó is rosszul válaszolhatott, sajátjának vallhatott be például egy olyan gyermeket, aki régóta a háztartásában él, de nem vér szerinti gyermeke (például partnerének a vér szerinti gyermeke). A számítógépes kérdezés kicsit csökkenti ennek a hibának az előfordulását: egyrészt mivel csak egyszer kell jó kódot megadni, az nem kerül ismételten átvezetésre, másfelől a program felhívja a kérdező figyelmét arra, hogy az összeírt gyermekszám nem egyezik a kérdőív elején megadottal. 


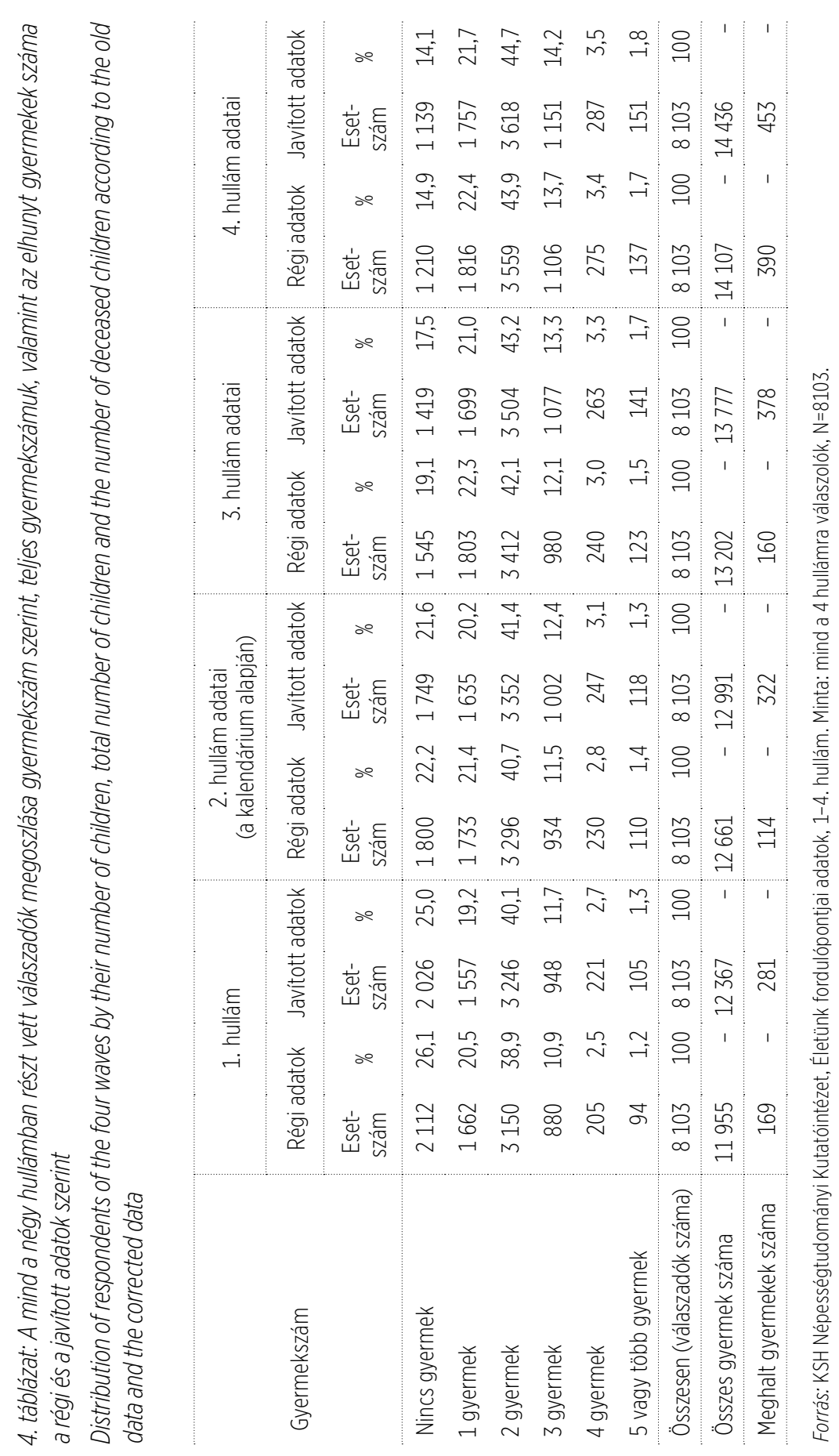


Egy másik típushiba az elhunyt gyermekek kihagyása volt. Sok esetben csak a 4. hullámban kerültek az adatbázisba olyan gyermekek, akik már régebben elhunytak. Számos olyan gyermeket rögzítettünk ekkor, akik régebben, esetleg csecsemőkorban hunytak el, és a korábbi hullámok során a pontatlan kérdésfeltevés miatt nem jutott a válaszadók eszébe, hogy beszámoljanak róluk (ez jellemzően az idősebb válaszadók esetében fordult elő).

Azon esetek száma sem volt elhanyagolható, amikor egyazon kérdőív kitöltése során ugyanaz a gyermek a háztartástáblába és a különélők közé is bekerült; de más hullámokból jellemzően kiderült, hogy már évtizedek óta nem él válaszadó szülőjével. Itt egyértelműen a kérdezőbiztosok hibáztak, hiszen nekik kellett volna ügyelniük arra, hogy a különböző típusú gyermekek a megfelelő helyen kerüljenek összeírásra. Ez tudatosította bennünk, hogy a kérdezőbiztosok oktatása során külön fel kell hívni a figyelmet a gyermekek összeírásának módjára.

Problémát okozott továbbá a 2. hullámban a kalendáriumos kérdezés. A különélő gyermekek egy része hiányzott a kalendáriumból (elképzelhető, hogy ezekben az esetekben nem volt megfelelő a kalendárium előzetes kitöltése); az együttélő gyerekek egy része pedig a kérdezés során nem került be a háztartástáblába, csak a kalendáriumban szerepelt.

A 3. hullámban nem bizonyult szerencsésnek minden egyes gyermekre feltenni, és 1-es számmal kódolni azt a kérdést, hogy „Örökbefogadott gyerek-e?”. Erre a viszonylag keveseket érintő plusz kérdésre a kérdezőbiztosok sok esetben hibásan 1-est írtak be, ez által a gyermek kikerült a válaszadó „vér szerinti gyermeke” kategóriából, és hirtelen megnőtt az „örökbefogadott” gyermekek száma. Érdemes lett volna inkább külön rákérdezni arra, hogy a kérdezettnek van-e örökbefogadott gyermeke, és másutt, vér szerinti gyermekeitől elkülönített helyen összeírni az adatait.

A javítás elsődleges célja az volt, hogy a gyermekek száma konzekvens legyen az egyes hullámok során. Másodlagos célja pedig, hogy a születési dátumokat is harmonizáljuk, ám ez sok esetben lehetetlennek bizonyult: a születési években 1-1 év, a hónapokban ennél nagyobb eltérés is gyakran előfordult. Így ezek javítására csak abban az esetben került sor, ha egyértelmű volt a megfelelő dátum (például ha három hullámban helyes volt az adat, és csak egyszer volt elrontva).

Fontos kiemelni, hogy e nagymértékủ javítás után is maradtak hibás adatok. Sok esetben ugyanis lehetetlen volt rájönni, vagy legalábbis valószínűsiteni, melyek a helyes adatok: melyek a válaszadó vér szerinti gyermekei, és melyek nem? Hogy került oda egy gyermek, aki sehol máshol nem bukkan fel? Emellett, ahogy már említettük, a születési dátumokat nem javítottuk szisztematikusan, hiszen 
elsősorban arra összpontosítottunk, hogy a gyermekszámok konzekvensek legyenek a hullámok között. A dátumokat javítottuk, amennyiben a gyermekszámok javításakor észrevettük, hogy azok is helytelenül lettek rögzítve. Ám ahol rendben voltak a gyermekszámok, ott nem kerültek átnézésre a dátumok. Ennek javítása amúgy is igen nehéz, hiszen szinte lehetetlen megtudni, hogy valójában mely évben, hónapban született egy gyermek.

\section{ÖSSZEGZÉS: HOGYAN KÉRDEZZÜK LE A GYERMEKEK ADATAIT?}

Amint láttuk, a válaszadók gyermekeinek az összegyűjtése, összeírása igen öszszetett feladat, amely sokféle hibalehetőséget rejt magában. Ahogy elemzésünk kimutatta, az Életünk fordulópontjai adatfelvételben javítás előtt, hullámonként a gyermekek mintegy 3\%-a hiányzott az adatokból. És noha nem elvárható, hogy egy ilyen jellegü összeírás során ne kerüljenek hibák az adatokba, itt nagyrészt olyan hibákról van szó, amelyeket megfelelő kérdezési technikával ki lehet küszöbölni - ez történt a negyedik adatfelvételi hullámban, amely során sikerült a korábbi adatokat pontosítani, a korábban kimaradt gyermekeket összeírni.

Melyek tehát azok a hibák, amelyek elkerülhetőek, és mire érdemes figyelni egy ilyen jellegü kérdezésnél? Először is, mindenképpen hasznos, ha van egy összefoglaló kérdés a gyermekszámra vonatkozóan. Ez lehetőséget ad arra, hogy tisztázzuk, mely gyermekekre leszünk majd kíváncsiak, valamint jó ellenőrzési támpontként szolgál a későbbiekben. Különösen fontos, hogy pontosan megmondjuk, mit értünk „gyermek” alatt (pl. a vér szerinti gyermeket), illetve felhívjuk a válaszadó figyelmét arra, hogy minden élve született gyermekéről - a már elhunytakról is - számoljon be. Az összefoglaló kérdés után kerülhet sor a gyermekek adatainak összeírására egy vagy két (esetleg több) táblában: a háztartástáblában és a különélő gyermekek táblában.

Az a legfontosabb szempont itt is, hogy a gyerekszámmal kapcsolatos kérdéseket hogyan fogalmazzuk meg. Ahogy láttuk, az Életünk fordulópontjaiban mind az első, mind a harmadik hullám kérdése azt sugallta, hogy a most is életben lévő gyermekekre vagyunk kíváncsiak (2. táblázat). A negyedikben került végül pontosításra, hogy az elhunyt gyermekeket is kérjük felsorolni. Nehéz kérdezési szituációt eredményezhet egy ilyen kérés, hiszen kellemetlen emlékek felidézésére kérjük a válaszadót. Olyan adatoknál, amelyekkel termékenységi elemzéseket kívánunk készíteni, mégis elengedhetetlen, hogy a már elhunyt gyermekekről is begyűjtsük az információkat. 
Egy másik fontos szempont, hogy a kérdezőbiztosok pontosan tudják, hogyan kell összeírniuk a gyermekeket. Tisztában kell lenniük azzal, hogy mely gyermekekre vagyunk kíváncsiak, és azzal is, hogy a különböző (a válaszadóval együtt élő, illetve tőle külön élő, esetleg meghalt) gyermekeket a kérdőív mely részébe kell beírni. A kérdezőbiztosok oktatása során külön időt kell tehát szentelni ennek a kérdésnek, hiszen ahogy tapasztaltuk, sok esetben rontották el a kitöltést: a válaszadóval nem együtt élő gyermekeket például hibásan beírták a háztartástáblába, esetleg utána még a különélő táblába is.

Az is fontos tényező, hogy laptopos kérdezés esetén a programba be legyen építve belső ellenőrzés. Ez azt jelenti, hogy miután összeírták a gyermekek adatait, a program az összeírt gyermekek számát összevesse az összefoglaló kérdés során megadott gyermekszámmal, és amennyiben a két szám nem egyezik, ezt hibaüzenettel jelezze a kérdezőbiztosnak. Ez garantálja, hogy a kérdőíven belül mindenképpen egyezzen a gyermekszám, ne forduljon elő, hogy például a válaszadó azt mondja, két gyermeke született, ám a kérdőívben csak egy gyermek adatai szerepelnek. Az Életünk fordulópontjai adatfelvétel negyedik hullámában a hiba elnyomható volt, tehát a figyelmeztetés után a kérdezőbiztos javítás nélkül is tovább tudott lépni (ennek az volt a célja, hogy ha valamilyen okból nem sikerül összeírni a megfelelő gyermekek adatait, ne szakadjon meg a kérdezés). Ennek ellenére elenyésző (67 darab) volt azon kérdőívek száma, ahol a két adat nem egyezett.

Tapasztalatunk szerint ezen tényezők figyelembe vétele nagymértékben javítja az adatminőséget. És noha csak törekedhetünk arra, hogy adataink hibátlanok legyenek, a fent felsorolt szempontok mindenképpen hozzájárulnak ahhoz, hogy termékenységgel kapcsolatos elemzéseink megbízhatóak legyenek. 


\section{IRODALOM}

Kapitány Balázs (szerk.) 2003: Életünk fordulópontjai. Módszertan és dokumentáció. Mühelytanulmányok 2. KSH Népességtudományi Kutatóintézet, Budapest.

Kreyenfeld, Michaela - Hornung, Anne - Kubisch, Karolin 2013: The German Generations and Gender Survey: Some Critical Reflections on the Validity of Fertility Histories. Comparative Population Studies - Zeitschrift für Bevölkerungswissenschaft, 38(1), 3-28.

Makay Zsuzsanna 2015: „Önnek hány gyermeke van?” Bevallott és elfelejtett gyermekek egyazon adatfelvételen belül 3-12 év távlatában. [Előadás]. „Fókuszban a család” konferencia, Pécs. Letölthető: http://demografia.hu/hu/letoltes/eloadasok/fokuszban-acsalad/Makay.pdf

Murinkó Lívia - Spéder Zsolt (szerk.) 2016: Felhasználói kézikönyv az Életünk fordulópontjai panelkutatás 1-4. hullámához. Kutatási Jelentések 97. KSH Népességtudományi Kutatóintézet, Budapest.

Ní Bhrolcháin, Márie - Beaujouan, Éva - Murphy, Michael 2011: Sources of error in reported childlessness in a continuous British household survey. Population Studies, 65(3), 305-318.

Régnier-Loilier, Arnaud 2014: Incohérence du nombre d'enfants déclarés entre les vagues de l'enquête française Generations and Gender Survey. Population, 69(2), 167-190. 


\section{FÜGGELÉK}

\section{Az első adatfelvételi hullám háztartástábláia}

11. Önnel együtt hányan élnek ebben a háztartásban? (kollégista, sorkatona, ingázó is)

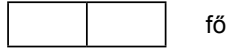

Kérem, közöljön róluk néhány adatot:

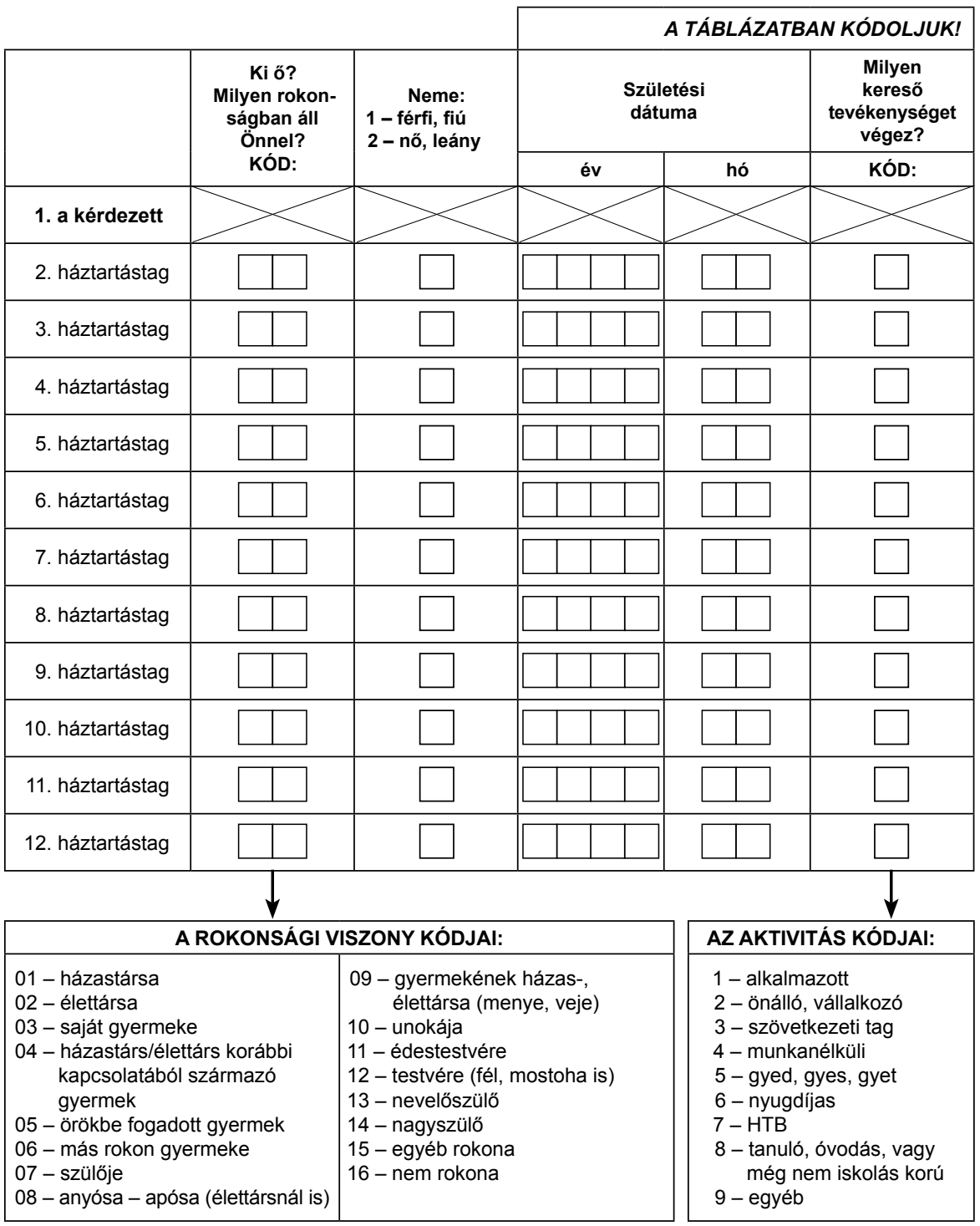




\section{Il. Az első adatfelvételi hullám „külön élő gyermek” tábláia}

13. Született-e Önnek olyan gyermeke, akivel jelenleg nem él közös háztartásban?

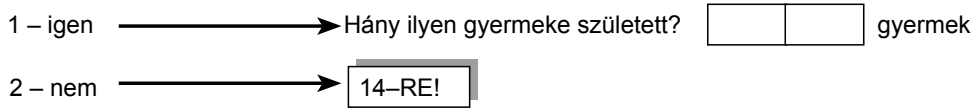

Kérem, közöljön róluk néhány adatot:

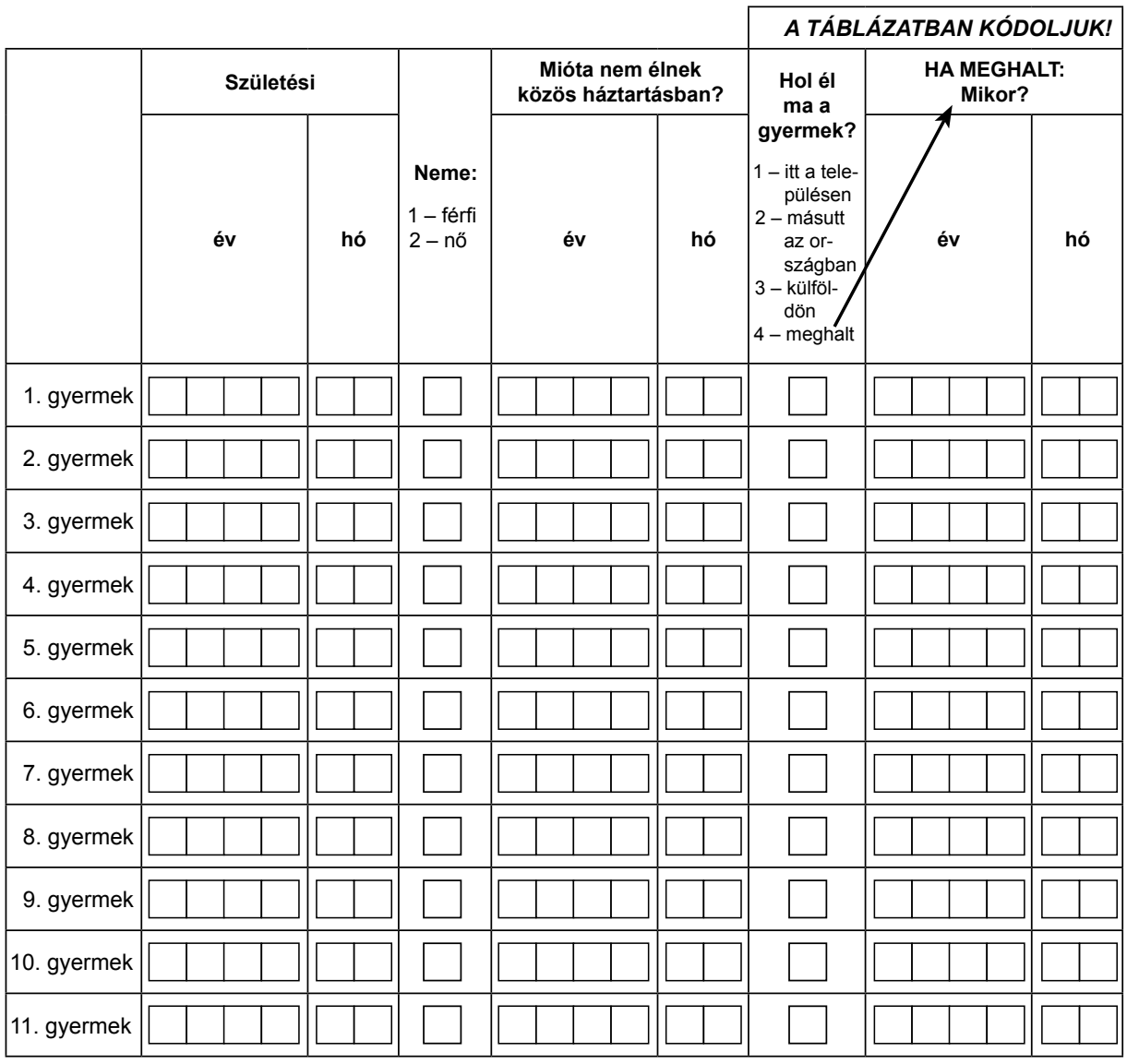



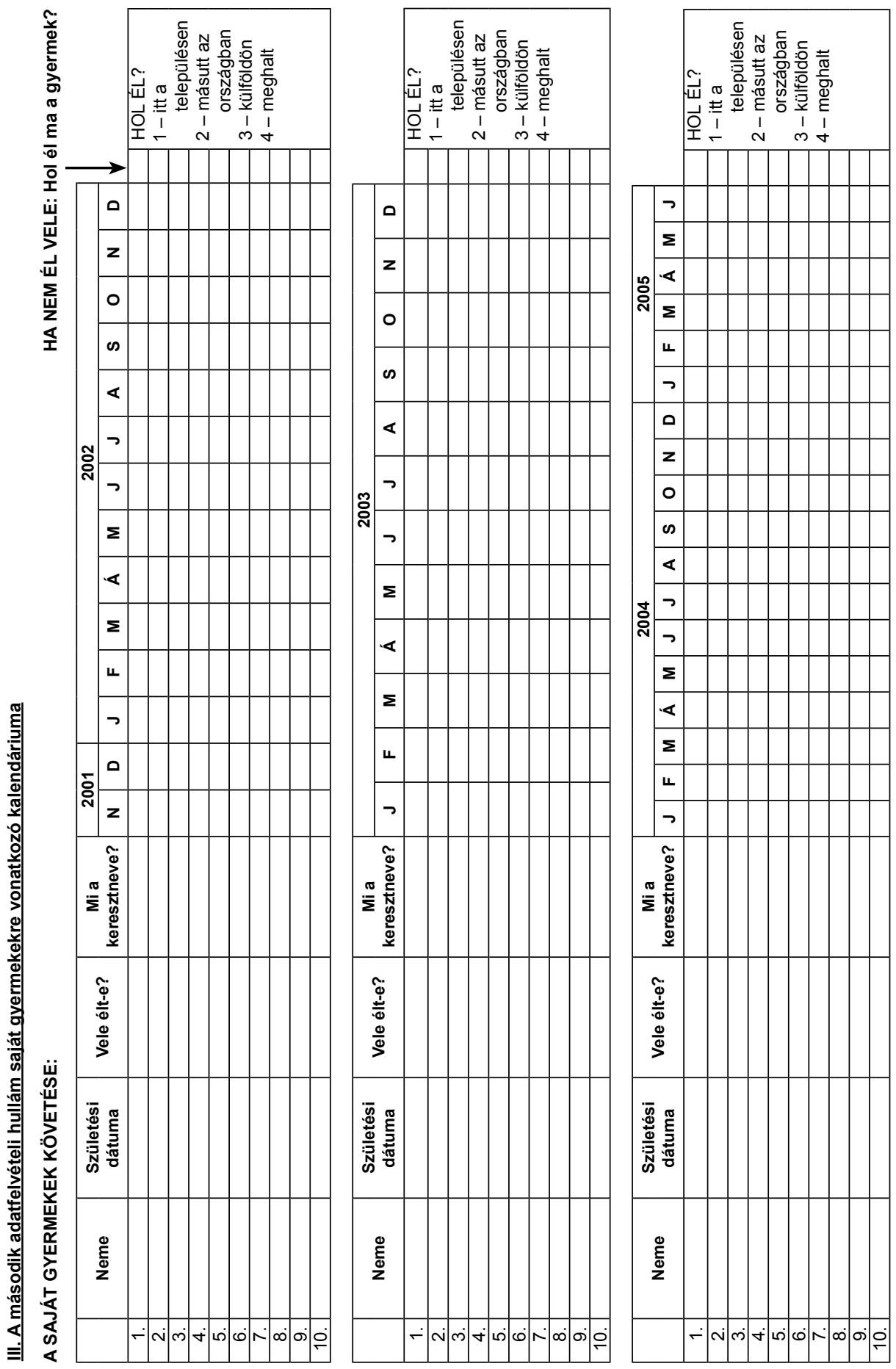


\title{
HOW SHALL WE ASK HOW MANY CHILDREN OUR RESPONDENTS HAD? LESSONS FROM A LONGITUDINAL SURVEY
}

\begin{abstract}
In the Hungarian Generations and Gender Survey (,,Turning points of our life course") the same respondents were interviewed four times between 2001 and 2012. Among other topics, data about their fertility history were collected, since one of the main questions of this research was about fertility and childbearing decisions. Data analysis shows however, that data about the number of children and the dates of birth were often incorrect: some respondents had for example less children in one wave than in a previous one. In most cases, wrong data had been collected because questions about children had not been asked precisely. Therefore a bigger data correction was carried out in order to make fertility data consistent over the four waves. In this study the reasons and the mechanisms of this correction are described. A special part is also devoted to the lessons learned. It is argued that by asking questions about fertility history appropriately and by making use of some technical tricks in the case of CAPI (computer assisted personal interview), most of these problems can be avoided and the quality of data improved.
\end{abstract}

